Cornell Law Library

Scholarship@Cornell Law: A Digital Repository

Cornell Law Faculty Publications

Faculty Scholarship

$5-1-2001$

\title{
Constitution-Making in Africa: Assessing Both the Process and the Content
}

\author{
Muna Ndulo \\ Cornell LawSchool, mbn5@cornell.edu
}

Follow this and additional works at: http://scholarship.law.cornell.edu/facpub

Part of the Constitutional Law Commons, and the Law and Economics Commons

\section{Recommended Citation}

Ndulo, Muna, "Constitution-Making in Africa: Assessing Both the Process and the Content" (2001). Cornell Law Faculty Publications. Paper 57.

http://scholarship.law.cornell.edu/facpub/57

This Article is brought to you for free and open access by the Faculty Scholarship at Scholarship@Cornell Law: A Digital Repository. It has been accepted for inclusion in Cornell Law Faculty Publications by an authorized administrator of Scholarship@Cornell Law: A Digital Repository. For more information, please contact jmp8@cornell.edu. 


\title{
Constitution-making in Africa: assessing both the process and the content
}

M. Ndulo

Public Administration \& Development; May 2001; 21, 2; ABI/INFORM Global

pg. 101

PUBLIC ADMINISTRATION AND DEVELOPMENT

Public Admin. Dev. 21, 101-117 (2001)

DOI: $10.1002 /$ pad. 163

\section{CONSTITUTION-MAKING IN AFRICA: ASSESSING BOTH THE PROCESS AND THE CONTENT}

\author{
M. NDULO* \\ Comell University, Ithaca, NY, USA
}

\section{SUMMARY}

This article examines the relationship between governance and development, and concludes that underlying the litany of Africa's development problems is a crisis of governance. Good governance would result in institutions that are more likely to adopt economic policies that would resolve the constraints that hinder economic development. In addition, it would make a major contribution to the reduction of war and conflict. It would do this by creating an environment for sustainable development to take place and thereby reduce poverty, the root cause of war and conflict. This calls for a critical examination of the question of governance in Africa with a view to identifying the obstacles to its establishment and the possible approaches to the development of systems of governance that give political space to all groups. Since the most important legal instrument in the scheme of good governance is the national constitution, the article seeks to identify some of the key issues that must be considered in the process of developing a national constitution if it is to be durable. It also addresses the conditions under which such constitutions should be developed if they are to be acceptable to the people of the country they are intended to govern. Running through the article is the theme that the establishment of good governance in Africa depends on the development of political systems that give people a sense of ownership of the political process. Copyright (C) 2001 John Wiley \& Sons, Ltd.

\section{INTRODUCTION}

Africa is both the least developed and, in terms of natural resources, the most endowed continent in the world. With a land area three times the size of the United States, and a population of some 600 million people, Africa enjoys the resources required to attain sustainable development, defined as increasingly productive employment opportunities and a steadily improving quality of life for all its citizens. The continent has vast mineral, oil, water, land and human resources. Yet, about 240 million Africans live on less than one dollar a day, have no access to safe drinking water and are illiterate. The ambiguity in Africa's position is revealed with particular clarity in relation to the production of food, a sector in which during pre-colonial times the continent was self-sufficient but is now increasingly dependent upon external supplies. On the face of it, the apparent inability of the African continent to feed itself is paradoxical, since one of the region's chief assets is its huge agricultural potential. It has all the conditions for becoming one of the world's major food baskets.

Unfortunately, Africa lacks the domestic capital necessary to translate its enormous wealth into realizable benefits for its people, and it has failed to attract sizable foreign investments to fill the gap. Africa receives only $5 \%$ of all direct foreign investment flowing to developing countries. This is in spite of the fact that investments made in Africa consistently generate high rates of return. For example, during the period 1990-1994, the average annual return on book-value of US direct investment in Africa was nearly $28 \%$, compared with $8.5 \%$ for US direct investment worldwide. At the root of the problem for Africa is the worldwide perception of it as an unstable, poorly governed, and conflict-ridden continent that cannot guarantee the safety of foreign investments. Africa's political instability has exacted a huge cost on its development efforts. In its 1989 report on sub-Saharan Africa the World Bank concluded:

... underlying the litany of Africa's development problems is a crisis of governance.... By governance

is meant the exercise of political power to manage a nation's affairs. Because countervailing power has

*Correspondence to: Muno Ndulo, Cornell University, Cornell Law School, 314 Myron Taylor Hall, Ithaca, NY 14850, USA.

Copyright (C) 2001 John Wiley \& Sons, Ltd. 
been lacking, state officials in many countries have served their own interests without fear of being called to account. The leadership assumes broad discretionary authority and loses its legitimacy. Information is controlled, and voluntary associations are co-opted or disbanded. This environment cannot readily support a dynamic economy.

United Nations' and multilateral lending institutions' reports are unanimous in noting that Africa's inability to realize its potential is largely attributable to its lack of good governance. There is growing international consensus concerning the central role a good, efficient, and capable government plays in the economic and social development of the country. The General Assembly has recognized that democracy, and transparent and accountable governance and administration in all sectors of society are indispensable foundations for the realization of social and people-centred sustainable development.

The United Nations Development Programme (UNDP) has defined good governance as: 'The responsible exercise of political, economic and administrative authority in the management of a country's affairs at all levels'. Good governance has many attributes. It is effective, participatory, transparent, accountable, equitable and promotes the rule of law and thereby creates a capable state. In this context, a capable state is defined as one that espouses good governance and is characterized by transparency, accountability in the conduct of national affairs, the ability to enforce law and order throughout the country, respect for human rights, effective provision of infrastructure, a limited role in the market economy, creation of a favourable policy environment and seeking to work in partnership with the private sector and civil society. Other important characteristics of a capable state are: acceptance of opposition and competitive politics, predictable, open and enlightened policy-making, a bureaucracy imbued with a professional ethos acting in furtherance of the public good, maintenance of fair terms of trade between the rural and urban sectors, and recognition and respect of the boundaries between itself and the private sector and civil society. These characteristics enable a state to effectively perform its role of developing the country and bringing about a better life for all its people.

The answer, therefore, to Africa's development quagmire lies in establishing democratic governance in African countries. It calls for a critical examination of the question of governance in Africa with a view to identifying the obstacles to its development and the possible approaches to the development of systems of governance that give political space to all groups, thereby avoiding conflict and political instability. If issues of governance were to be resolved, Africa could be one of the fastest-growing regions in the world. Good governance would result in governments that are more likely to adopt economic policies that would resolve the constraints that hinder sustained economic development. A 1996 US trade policy document describes Africa as the 'last frontier for American businesses'. A number of countries are beginning to register positive growth. Aggressive entrepreneurs around the world are rediscovering the continent, or at least its rich mineral resources. But progress remains fragile and could easily be reversed, and it therefore needs to be consolidated. There is much to be done to translate the recent improvements into progress that is sustainable and that will have a positive impact on the lives of the poor. Not since independence have both the hopes and the challenges in Africa been simultaneously so great. Africa remains host to the largest population of refugees and displaced persons on any continent. Too many Africans are trapped in conditions of grinding poverty, face violence and abuse daily, suffer under corrupt and oppressive regimes, and are condemned to live their lives in squatter settlements or rural slums with inadequate sanitation, schooling and health facilities.

The most important legal instrument in the scheme of good governance is the national constitution. Thus a major part of the answer to Africa's present predicament lies in the development of constitutions that can stand the test of time and that deliberately structure national institutions engaged in the management of the country in such a way as to ensure that a capable state is created. In the past 12 years, Africa has been the scene of constitutional changes unmatched on the continent since the end of European colonialism in the 1960s. In 1989 there were only five African countries that could be described as democracies, but today well over half of the countries in Africa have adopted democratic systems of governance. Yet, in many of these countries, the advances in democracy, though real, remain fragile and need strengthening. Reversals in such countries as Lesotho and Sierra Leone remind us that we should not become complacent and assume that democracy has taken hold on the African continent. Further, the tragedies in Rwanda, Somalia, Liberia and Zaire (now Congo) graphically illustrate the horrendous consequences of failed constitutional arrangements. The future of democracy in Africa is predicated on 
the development of viable constitutional arrangements that set up viable institutions within which to conduct the business of governance and which foster an environment where peace and development can flourish. Such arrangements will ensure that the exercise of governmental authority is exercised in a predictable, responsible and legally regulated way to the satisfaction of civil society.

It should be emphasized, however, that in the constitution development process it is not for outsiders to tell African countries what should be in their constitution. Every African country must decide on its own constitution. There is a well-founded suspicion in Africa as a whole, of anything smacking of superior wisdom from outside. Like much else in African history, it goes back to the days of slavery when the horrors of the slave trade were presented in Europe and America as positive deliverance of its victims from the scourge of ignorance, superstition and squalor. When colonialism succeeded slavery, that too, in its turn, was presented as a duty of Christianity and civilization towards a race still in the infancy of mankind and without the blessing of the art of good governance or of spiritual progress. No other continent has suffered so much from the solicitude and pontification of others as Africa. Nonetheless, respect for national circumstances does not mean that there is a less demanding path to democracy for Africans, nor that undemocratic forms of government are tolerable provided they conform to the outward appearance of democracy, such as holding of stage-managed elections.

\section{COLONIAL LEGACY}

Africa's problems are, to a very large extent, rooted in its past. The continent has suffered a painful history that includes some of the worst human tragedies in living memory, slavery, colonialism and apartheid. As a direct result of these tragedies, when African countries won independence, they faced formidable constraints to development. These included underdeveloped human resources, political fragility, and insecurity rooted in ill-suited institutions. Moreover, this legacy will continue to hamper African development for decades to come. But Africa should draw lessons, strength and determination rather than despair from the past. The serious problems facing Africa should generate a predisposition to engage in a fundamental re-examination and redirection rather than a feeling of hopelessness. Any avoidance of an unpromising future requires transcending not only unfavourable indicators for the decades immediately ahead, but also unhelpful inheritance from the past.

Traditional African society had its own system of social and political organization. Gluckman, for instance, writing about the Lozi of Zambia, observed that the Lozi had a complex economy which required many people to cooperate in various productive activities. The basic unit of organization in the structure of their economic, political and domestic system was the village. It was the centre from which they exploited gardens and parcels of land. The village was led by a headman who represented the village to the King in Council, and represented the village at the Council headed by the Chief. The Chief governed with the assistance of councillors (Gluckman, 1967). Since the advent of colonialism, African societies, however, have experienced protracted economic and social changes. At the Berlin Conference of 1884, the colonial powers partitioned Africa into territorial units. African kingdoms, states and communities were arbitrarily divided; unrelated areas and peoples were just as arbitrarily joined together as were united peoples torn apart. The era of colonialism initiated, and that of independence consummated, a dynamic process of disruption in tribal organization and tribal life. Unlike in pre-colonial Africa, the financial, political and military security of African societies no longer depended on traditional organizations and custom. There has been a departure from agrarian self-subsistence communities to a money economy dependent on the capitalist economic system. With such fundamental changes, the human institutions governing African societies have also had to change. The foremost act of disruption was the unification of ethnic communities under the umbrella of sovereign states created pursuant to the Berlin Conference of 1884 with overriding powers of political control within their whole area of jurisdiction. Dislocation of African peoples from their lands and communities continued throughout the colonial period as the needs of the colonial economy expanded, further undermining any tribal economy or social organization that might have been left in place after the initial establishment of colonial rule.

Colonial rule was philosophically and organizationally elitist, centralist and absolute. There were no representative institutions. The colonial administrations not only implemented policy, they made it as well. Authoritarian 
forms of government everywhere express their character by giving relatively unbound discretion to 'the man on the spot'. In Africa, this philosophy of governance was expressed in law principally by rules that gave almost unlimited discretion to colonial officials, and the absence of formal controls over its exercise. As colonial rulers sought expedient interlocutors, they distorted or destroyed pre-colonial governance systems by creating or encouraging arrangements such as indirect rule, which made existing local chiefs more despotic and which created new ones (warrant chiefs) where none existed before. During the colonial period African societies became divided into two - the rural and the urban - with two distinct cultures. Traditional culture was found in the rural areas where the great majority of the people lived and which was largely outside the framework of colonial elitism and the 'modern' culture found in urban areas. The urban economy and culture was the link between the metropolitan country and the colony in the export of raw materials. Colonial economic policies kept African economies small, excessively open, dependent and poorly integrated. The result was that the colonial state was characterized by a huge gap in the standards of living between the rural and urban areas.

This rural/urban divide, dating from the colonial period, continues today. The rural areas continue to be neglected, marginalized and impoverished. The state is extremely weak and is almost completely irrelevant as a provider of services in rural areas. There is mounting evidence that the International Monetary Fund (IMF)/World Bank stabilization and structural adjustment programmes that are in place in almost all African countries have worsened the situation. For instance, the withdrawal of state marketing agencies has exposed poor farmers to exploitation by large city traders. It is further reinforced by the lack of popular participation in governance and exacerbated by the lack of effective devolution of power to local communities.

Moreover, this colonial legacy has endured long after independence. Colonial rule bequeathed on independent African states undemocratic governments and bureaucracies that emphasized hierarchy, compliance and discipline, without addressing other equally important concerns such as public accountability, responsiveness and participation. Many governments that emerged after independence soon became undemocratic, over-centralized and authoritarian. Predictably, political monopolies led to corruption, nepotism and abuse of power. African presidents replaced their colonial governors in fact and in deeds. Like the colonial governors, they became the sole embodiment of the social will and purposes of the countries they ruled. We saw the emergence of repressive single or no-party systems of government. With one-party systems, power came to be concentrated in one man. Dissent, for which there had always been a secure and honoured place in traditional African society, came to be viewed with ill-concealed hostility, almost as if it were treason. Multiple parties, even if originally formed around national agendas, generally tended to lead to ethnically based parties that made African states ungovernable. Single-party or military rule was often regarded as a viable and sometimes desirable solution to the ethnically based parties in Africa's new modern states (Mubako, 1973, p. 67). Ultimately, the party supplanted the machinery of the state and the differences between the two became blurred (Gertzel et al., 1994, p. 101). Thus, 30 years into independence, Africa was left in crisis, a litter of failed states whose characteristics include:

- highly centralized systems of governance;

- excessive state control coupled with limited capacity to govern;

- arbitrary policy-making and abuse of executive power;

- erosion of the boundaries between the state and civil society;

- weak institutions of both state and civil society with few countervailing forces to the executive branch of authority;

- unaccountable bureaucracies;

- widespread corruption;

- unenforced or unjust legal systems;

- limited participation in governance by the general citizenry; and

- preferential access to power and resources often determined by religious, ethnic or geographical considerations (this political rigidity shut off the springs of activity in the people).

As Obasanjo observed, ' the men and women of spirit who are the leaven of every society either began to go into exile in foreign countries or withdrew into stultifying private life; to their loss yes, but to the even greater loss of 
society at large'. The result was unprecedented economic decline and mismanagement, resulting in unimaginable poverty (Obasanjo, 1988). In fact the dreams of prosperity following independence and self-rule became the nightmare of insecurity and poverty.

\section{CONTENT OF A DEMOCRATIC CONSTITUTION}

Economic recovery in Africa must, therefore, begin with a recuperation of those values which are acknowledged worldwide to be the foundation of every true human society. These values are in turn the foundation of social creativity and democratic governance. African states must establish stable political and constitutional orders that promote development and aid the conquest of poverty, hunger, disease and ignorance, while also guaranteeing citizens the rule of law and equal protection of the law regardless of the citizen's sex, colour or ethnic origin (Bentsi-Enchil, 1969, p. 65). If the continent is to respond successfully to the needs of its people and realize its dreams of rapid economic development, it will have to apply careful thought and inquiry to the proper organization of political, economic, and administrative institutions to ensure the proper governance of the nation state (Gloppen, 1997, pp. 264-265). The aim should be to achieve a constitutional order that is legitimate, credible and enduring, and which is structurally accessible to the people without compromising the integrity and effectiveness of the process of governance. Constitutional democracy in Africa will inevitably involve multiple, or concurrent, constitutional orders rather than a single centre of authority and power, especially as African countries are characterized by large territorial, multi-ethnic groupings, high rates of illiteracy and poor communications infrastructure.

In general terms, constitutional democracy concerns the following principles:

- using the constitution, as a supreme and fundamental law, to regulate and to limit the powers of government, and to secure the efficacy of such limitations in actual practice;

- ensuring that the legitimacy of the government is regularly established by requiring that governmental powers are not assumed or exercised except with the mandate of the people given at periodic intervals through free and fair elections or referenda that are executed and administered according to the constitution and well-defined electoral laws;

- protecting the fundamental rights of the people;

- resolving disputes, including disputes relating to the constitutional propriety of legislation and other government acts, impartially and in accordance with the constitution and by regular, ordinary courts that are independent of the disputants;

- applying of ordinary laws regarding the execution of governance and adjudication of disputes in conformity with the limitations imposed by the constitution and in accordance with the procedure for law-making prescribed therein and ensuring that such procedures conform to internationally accepted norms;

- holding political leaders and government officials accountable for their actions to constituents through clearly formulated and transparent processes;

- assuring the safety and security of citizens and the rule of law such that contracts can be fairly enforced both between the public and private operators and between private operators and the state;

- requiring public agencies to be responsive to the needs of the public and to promote social and economic development for the benefit of all citizens in an equitable manner and not just a particular ethnic group; and

- providing information that permits accountability to be achieved, laws to be carefully applied, markets to function and people to be creative and innovative (Third World Legal Studies, 1988; Shinhivi, 1995).

Thomas Paine, in his work 'Rights of Man' written in 1752, provided the following definition:

A constitution is not the act of a government, but of a people constituting a government, and a government without a constitution is power without right. A constitution is a thing antecedent to a government, and a government is only the creature of a constitution (Ojwang, 1990). 
It represents the basic structure of any organized society. Formal or informal, written or unwritten, its existence, in whatever form, is inevitable (Ojwang, 1990). When one speaks of a modern constitution, however, notions of formality emerge (Gloppen, 1997, p. 39). In post-colonial Africa, this has come down to a single written document, to a charter for the exercise of political power. Some African scholars have criticized the move towards written constitutions and the current constitutional arrangements on the grounds that they are based or follow too closely on Western models of governance, rather than on African ideals of governance, and have questioned the relevance of Western models to the African condition (Howard, 1996, p. 16; Yansane, 1996). Be that as it may, the impact of history seems clear - one may interpret history, or reinterpret it, but no one can repeal it. Besides, while transplanting European models into Africa might be problematic, the motives of some of those who advocate for 'African solutions to African problems' many times are suspect. Many post-independence dictatorships and indeed the African one-party system of governance in Zambia, Kenya, Tanzania and elsewhere in Africa were justified on the grounds that they were a variant of democracy best suited to the peculiar African circumstances and, at the same time, they were a natural facilitator for economic growth and promoter of national unity (Zimba, 1984, p. 119). Today it is quite evident that these justifications had little to do with 'African concepts of governance' and more with the consolidation of political power through the elimination of all political opposition (Mubako, 1973, p. 67).

\section{DEVELOPING A VIABLE CONSTITUTIONAL ORDER}

A serious search for viable constitutional arrangements in African states must begin with the frank identification and examination of the specific social, political and economic conditions present in African countries. As Seidman has observed, hitherto, most African constitution drafting that took place in the post-colonial era can be analogized to:

... an elaborate buffet, with elaborate constitutional provisions from other existing constitutions spread across the glittering sideboard, from which the constitutional maker filled her plate to her taste... sentences, paragraphs, whole sections and chapters float from one constitution to the next (Seidman, 1987, p. 56).

This was done without any serious attempt to relate the process to the social and political conditions in the countries concerned. This is not the correct approach for enacting legitimate constitutions that would adequately address African problems, and be consistent with Africa's cultural and historical peculiarities. As Judge Chaskalson has observed: 'constitutions are shaped by history. What is appropriate for one country in the light of its history, is not necessarily appropriate in another country with a different history' (Chaskalson, 1995). Overall one can accurately say that 'many of these piecemeal constitutions have been symbolic at best, and totally irrelevant at worst' (Wing, 1995).

There are several conditions that are specific to the African situation and which, unless addressed, would impact negatively on good governance in an African context:

- There is the need in each country for sufficient national unity, or cohesion, to generate social and political power. This unity and cohesion must be strong enough to enable the diverse peoples that make up each state to achieve purposes of well-being and development that are beyond their reach as separate units.

- African states need to accommodate the vast ethnic diversity that exists on the continent and acknowledge institutionally the intensity of the attachment the Africans have to their ethnicities. Unfortunately, in much of the continent the pattern of ethnic relations has been characterized by growing self-consciousness and, at times, intolerance, intransigence and intemperance (Anglin, 1994). Against this background the issue of ethnicity could potentially be destabilizing to the democratic process. Democracy may magnify rather than reduce the adverse effects of ethnicity.

- African states need to accommodate the significant racial minorities that exist in their countries. Constitutions must deal with this fact sensitively, not only consciously acknowledging the fears and apprehensions of racial minority groups, but also meeting their legitimate demands and involving them, in a meaningful and satisfying 
way, in the political systems that are evolved for nation-building. The issue of ethnic or racial minority protection will not be solved by simply being ignored. It has to be addressed in a proactive manner.

- The search for viable constitutional arrangements must acknowledge the newness and artificiality of African states which were, for the most part, recently and arbitrarily created during the colonial period. Basil Davidson identified the central role played by the Berlin Conference and various post-World War I adjustments, in drawing and redrawing the colonial map, and hence the post-independence map, in a way that made no historical, geographical or ethnic sense, as one of the main causes of the instability that is the root cause of the failure of African development (Davidson, 1992, pp. 160-161).

- The quest for a viable constitution must anticipate and prepare for the general unfamiliarity that most of the peoples in an African state have with the philosophy and machinery of modern democratic governance.

- A viable constitution must accommodate the general economic and social backwardness that exists in these countries and the consequential need and urgency for development on all fronts simultaneously.

- African constitutions cannot ignore the disproportionate economic and social importance of public office to individuals in the midst of widespread poverty and ignorance.

- The search must recognize the temptations of arrogance, discrimination, abuse of power and corruption assailing persons in office (Mbeki, 1995, p. 10).

- It must face the influence of money in the electoral process, especially in economies where a large percentage of voters are unemployed (Bentsi-Enchil, 1969, pp. 65-68). This last situation is worsened by the fact that most opposition parties in Africa lack resources to operate effectively, thus the funding of political parties should be addressed. The principle of government funding of political parties is well established across the democratic world. In the absence of state funding arrangements, the party in power has an undue advantage as it has access to state resources and institutions to push its political agenda.

- There is the problem of the inequality of the sexes perpetuated by cultural values and traditional roles assigned to women (Simons, 1968). As Mills observed, only complete equality between men and women in all legal, political and social arrangements can create the proper conditions for human freedom and a democratic way of life (Mills, 1869, quoted in; Hel, 1996, p. 111; Andrews, 1995). The goal should be as the Beijing Conference declared: to remove all obstacles to women's active participation in all spheres of public life and private life through a full and equal share in economic, social, cultural and political decision making (Fourth Conference on Women, 1995, p. 17).

- There is also a need to build a free and vibrant press. Only a free press can provide citizens with a range of information and opinions on the actions of the government, including fiercely critical views. This enables citizens to choose their representatives in an informed manner and to force state officials to respond to the desires of the public (Fiss, 1996, p. 142). In addition, a free press, by exposing wrong-doing, encourages accountable behaviour by public officials and politicians and discourages corruption. Further, a free flow of accurate information has economic implications in that a competitive market economy requires that economic actors have access to relevant, timely and reliable information. The less available or credible the information, the greater the uncertainty and risk, and therefore the cost, of committing capital or labour. In many African countries, governments continue to own newspapers. As many of the papers are unable to survive without government subsidies, they practise self-censorship in order not to run foul of the hand that feeds them.

- There is a need to define and to assess the role of the military in African states. It is essential for a democratic society that the military be respectful of the democratic process. In some parts of Africa, especially West Africa, the military have proved to be the greatest threat to the development of democratic governance. The examples of Nigeria, Gambia and Sierra Leone illustrate this point (Anglin, 1998).

- There is the need to encourage the development of a viable civil society. Civil society in democracies provides the checks and balances that assist in the regulation of governments. In Africa, years of one-party systems of governance and military regimes have hindered the development of powerful civic organizations that could act as countervailing forces to governments.

- The role of traditional institutions in modern African political systems must be addressed.

- Finally, a serious search for viable constitutional arrangements must respond to the need to decentralize power. 
A constitution that aspires to be legitimate and authoritative as the fundamental law of any state in Africa, if it is to succeed, must address the issues identified above. A constitution affects the lives of all citizens and ought, therefore, to address the concerns of all citizens regardless of their ethnicity, colour, gender and station in life. The late Chief Justice of South Africa, Justice Ismail Mohammed, observed in a recent judgment in Namibia:

The constitution of a nation is not simply a statute which mechanically defines the structures of government and the relations between the government and the governed, it is a 'mirror reflecting the national soul', the identification of the ideals and aspirations of a nation, the articulation of the values binding its people and disciplining its government.

A constitution ought therefore to be an autobiography of the nation. Reflected in the constitution should be the lives of all its citizens, young or old, male or female, rich or poor, straight or gay. People should be able to look at the constitution and see themselves and their lives within its pages and their protection within its words. The people must feel a sense of ownership of the document and see themselves and their history in it before they can respect, defend and obey it (Singhvi, unpublished, International Round Table on Democracy and Constitutional Development, 1995). Van der Vyer has observed that 'superimposed constitutional formulae, or constitutional arrangements that ... do not address the real causes of discontent, are sure to generate their own legitimacy crisis' (van der Vyer, 1991).

Beyond the essential ingredients of a democracy, a democratic constitution should be seen as a liberating document that not only limits the powers of the state and its institutions, but also guarantees the kinds of liberties and freedoms that will make the pursuant of happiness and self-fulfilment a reality for the people. It should guarantee equality of opportunity for all citizens irrespective of gender, race, religion or ethnic background. Equal opportunity for all is a mark of true liberation. It ensures that benefits of economic development accrue to the many and not to the few and that all citizens have a chance to live up to their potential and to achieve self-fulfilment.

\section{DEVOLUTION OF POWER AND THE ACCOMMODATION OF TRADITIONAL AUTHORITIES}

In a typical African state a large percentage of the people remain outside the formal structures of the state and rely on self-help and reliance for their survival. Many of the people operating outside the formal structures of government are in rural areas. There is a critical need for the devolution of power which is a means of not only improving governance and enhancing the accountability of leaders but also making the state a participant in people's lives. Post-independence African governments, like their colonial predecessors, tend to be overly centralized. In the institutional sense, centralization of power refers to the constitutional concentration of power in the hands of a few executive offices and, therefore, a few people. This greatly undermines the constitutional importance of courts, legislatures and sub-regional governments. This is usually reinforced by the tendency of most governments to concentrate the most critical human and financial resources at the headquarters, while leaving rural administration with a lean administrative structure that lacks adequate resources or discretionary authority. A major feature of any centralized state is the preoccupation it has with bureaucracy and planning and, hence, the preference for concentrated structures, rather than diversified and decentralized institutions that emphasize the grassroots empowerment of the people. Another feature is financial centralization. The central state collects all of the most important and buoyant tax resources and makes scarce funds available to sub-national organs. Compounding this problem is that financial transfers to sub-regional organs are done via grants which are given on a sporadic, rather than on a regular and systematic basis.

Effective devolution of power to local authorities entails the existence of local communities endowed with democratically constituted decision-making bodies and possessed of a wide degree of autonomy with regard to their responsibilities, the ways and means by which those responsibilities are exercised and the financial resources required for their fulfillment. Devolution of power to local communities has been recognized in many parts of the world as one of the cornerstones of democracy (European Charter of Local Self-Government, ETS No. 122). The right of citizens to participate in the conduct of public affairs is more directly exercised at the local levels. The existence of local authorities that are given real responsibilities can provide an administrative set-up 
which is both effective and close to the citizen. Unlike more centralized systems, local government provides for more flexible responses attuned to local needs. It opens opportunities for innovation and experimentation in policy formulation and delivery. It can alleviate the workload of over-stretched central government, something that is especially important in Africa in view of the numerous tasks of development and transformation that face a typical African government (Simeon, 1995).

Very few current African political systems have made any serious efforts to decentralize power. Even among those systems which profess commitment to it, there is a wide gap between political rhetoric and reality (Chikulo, 1984). African governments tend to 'co-opt' or, in extreme cases, abolish social institutions that they determine to be 'harmful' to their interpretation of nation-building. In reality, this includes anything that threatens the ruling party's hold on central government. The results of the current arrangements not only waste resources, but also encourage corruption in central government institutions and lower the ability of lower-level government institutions to expand or even to maintain existing infrastructures. In addition, because power is not decentralized, the struggle to control the central government becomes a matter of life and death among the political leadership. Observers have noted that African states tend to be strong in those areas in which they ought to be weak (repressive power) and weak where they ought to be strong (popular mobilization and responsiveness) (Paul, 1988). The process of democratization must go hand in hand with that of devolution of power to local communities. It is not enough to have democracy at the national level; it must be complemented at the sub-national and community levels. Societal and state institutions must exist as partners in social engineering. They must seek to empower the ordinary people in matters of governance. Democracy implies self-governance. Community-based social and political institutions ought to be the building blocks of a new and effective African polity.

Any examination of the modalities of effecting the devolution of power in Africa must, among other things, address the issue of the future of traditional institutions of governance in modern African political systems (Ampem, 1995; Constitution of Uganda, Article 246(1) 1996). There is a consensus among most Africans that traditional leaders, such as chiefs, should have a role in the governance of the state. But the exact role they should play is a source of disagreement and, as a result, their role remains largely undefined. For example, since 1994, nearly 800 South African chiefs and kings have complained that they do not have a proper role in the new South African political system. Ongoing conflict has been reported between elected local structures and traditional leaders, with some local structures refusing to recognize traditional leaders (Mail Guardian, Johannesburg, 23 October 1998). There is need to accommodate traditional leaders in constitutional arrangements or, at least, face up to their existence. For instance, they could be incorporated into the local government system and form the nucleus of that system. This could, quite conceivably, enhance the legitimacy of local government structures in the rural areas. In these areas, traditional leaders provide the link between the people and the external world (the government). Reaching those communities effectively requires one to confront this reality. If colonial powers were shrewd enough to use traditional institutions in administering the colonial state (Lugard, 1905, pp. 149-150), why should modern African political systems not make use of them in efforts to reach out to small communities building national consensus and cohesion (Nhlapo, 1995)?

It is important to find a place in the national political system for structures and institutions which cannot be wished away. The reality in many African countries is that the majority of the rural population live their lives within a traditional social and cultural context. For example, even in highly urbanized South Africa, about $60 \%$ of the people live in rural areas under traditional leaders (Mail Guardian, Johannesburg, 23 October 1998). The people in the rural areas, in the absence of legitimate local institutions, have been driven to reliance on informal institutions for day-to-day ordering of their affairs and of society, especially in the area of dispute resolution. It would therefore be a mistake to sideline traditional institutions and establish wholly alien institutions that will have to establish their legitimacy with the people over time. Since democracy means involving the various communities in a country in the governance of their affairs, it is imperative that rural communities should not be ignored in any democratic arrangement. Every effort should be made to integrate traditional institutions into the modern political structures so that all institutions are made accountable and responsive to the people. The state's vital interests in public order and stability, it would seem, are enhanced, rather than diminished, by the accommodation of traditional governance within the modern political systems of governance (Mail Guardian, Johannesburg, 23 October 1998). 
In advocating the accommodation of traditional structures in modern political systems, one should not ignore the fact that these institutions can at times be oppressive, exploitative, discriminatory and intolerant, especially to women and children (Ndulo, 1981, p. 179). The argument, however, is not that traditional institutions are perfect. Rather, it is that it is more effective to build democracy and effective governance through the familiar than the unfamiliar. Since the goal is to establish a democratic order, the need to incorporate traditional institutions into the modern political system cannot take precedence over the needs of a democratic society (Mbeki, 1995, p. 11). With regard to objections that these institutions are gender-discriminatory, governments must address the areas that need reform and discard the discriminatory aspects of traditional institutions and confront the traditional values that underpin gender discrimination and authoritarianism (Constitution of South Africa, Article 211(3); Constitution of Namibia, Article 66(1), 1987).

\section{NATURE OF THE DEMOCRATIC PROCESS}

In a democracy, the following conditions are deemed essential:

- System-wide pluralism - there should be no hindrance to alternative ideas, institutions and leaders competing for public support.

- Freedom of expression and association, and the protection of human rights. Among all the virtues, plain speech is one most necessary to the success of a democratic enterprise. Unless a people tell one another the truth about what they know and think and see, they cheat themselves of their courage and destroy the chance of their freedom. This is because democratic institutions do not renew themselves as effortlessly as flowering trees. They require cultivation by people brave enough and honest enough to admit their mistakes and to accept responsibility for even their most inglorious acts. It is not easy to tell the truth and most people seldom get it right, but repeated and familiar failures do not excuse people from making the attempt.

- An independent judiciary which has the power to rule on the constitutionality of legislation is needed (Nwabueze, 1977, p. 267; see also Agunda, 1983, p. 18).

- Accountability of the political leadership to the governed on the basis of openness, probity and honesty. The concept of those who govern being accountable to the people is at the heart of every democracy. Without accountability, there is really no democracy. It is society's insurance policy against those who form the government at any given time.

- A non-partisan, ethnically diverse and professional civil service that is accountable to the governed (BentsiEnchil, 1969). In a young democracy, an independent civil service could act as a hedge against anarchy when there are unavoidable clashes among political leaders.

- Periodic elections for the leaders to obtain the consent of the citizens and allow the voters to decide whether to renew the mandate of existing leaders or to elect new ones. This must be in the context of the multi-party system. People should not only be afforded the opportunity of having regular elections at all levels of government to vote for the party of their choice but, if they so should wish, they must be afforded the opportunity to remove from office any party exercising power. This can only be done effectively in a multi-party political system. To guarantee the acceptance of the elections by the people as free and fair, it is important that there are instituted independent election mechanisms to ensure that the elections meet these criteria.

The process of democratization, however, goes beyond the question of simply installing a multi-party system (Report of the Secretary General of the United Nations, 1991, p. 76). The demands for a multi-party system are easier to meet than a comprehensive demand for democracy. Democracy means the freedom of the people in their daily lives to determine their destinies, their right to build their own organizations, residences, schools and cultural institutions. To a large extent, democracy is less of a formalistic system than an attitude. It is a way of approaching the business of government, of setting up rules for government, of creating enough checks and balances that the government is less dependent on individuals and their personal whims, and more on systems and processes (Hand, 1960, pp. 189-190). Where citizens of a country have no sense of democracy and are unwilling or unable to insist that their leaders deliver democracy, a written constitution, however eloquently it proclaims democracy, will be 
insufficient to guarantee it (Ndulo, 1997, p. 174). Additionally democracy depends on certain values such as tolerance and trust that cannot be secured in a constitution. Rather, these values, to gain a foothold in a given country, depend on the political will of a nation.

\section{SYSTEM AND EFFECTIVE REPRESENTATION}

As observed, free and fair elections are indispensable elements to democratic governance. In addition, they are the obvious and traditional way of ensuring accountability and providing an institutional framework for the peaceful resolution of conflicts among competing political parties (Document of the Copenhagen Meeting of the Conference on the Human Dimension of the CSCE; American Convention on Human Rights Article 16; African Charter on Human and Peoples' Rights, Article 13; American Declaration of the Rights and Duties of Man Article xx; Council of Europe Convention for the Protection of Human Rights and Fundamental Freedoms, First Protocol Article 3; International Convention on Civil and Political Rights, Article 25). However, when the rules of the game are not universally accepted and respected, the process becomes controversial and a source of conflict rather than a mechanism for resolving strife (Anglin, 1994). Elections must be organized in a manner that ensures the maximization of the participation of all stakeholders in the political system. Unfortunately, many elections in Africa have been disputed, and have sometimes led to conflict rather than the advancement of democracy. In the Congo (Brazzaville), for instance, the 1992 election precipitated an incipient civil war between supporters of rival presidential contenders. Similarly, the May 1998 elections in Lesotho led to a total breakdown of law and order and the intervention of the Southern African Development Community's military forces to restore law and order in the country. The 1996 Zambian elections led to unprecedented tensions in the country and to an attempted coup (Post News Paper, Lusaka, 29 October 1997).

National elections are often manipulated by the party in power, and often result in substantial minorities being unrepresented in Parliament or feeling cheated by the process. In addition, many elections have been riddled with irregularities not always calculated to defraud, but which are sometimes a result of the sheer inability of the state to effectively conduct such a formidable managerial and logistical undertaking (Report of the Commonwealth Observer Group to the South African Elections 1994; Final Report of the UN Observer Mission in South Africa, 26 May 1994). As Chazon has observed: 'in Africa, elections provide ritual occasions for sanctioning the existing power constellation but allow for precious few opportunities for affecting the composition of the ruling circles or polity outcomes' (Chazon, 1988, p. 138). The utility of elections is further undermined by the fact that the electoral process is often not accompanied by the building of institutions that foster accountability and greater transparency in the governance of the country (Human Rights Watch/Africa, Zambia, 1996). The challenge here is to make elections an effective tool for choosing representatives of the people, as well as an integral process in the construction of a democratic state. At a minimum, national elections must be organized in a manner that ensures the maximum participation of all sectors of the population in the political system (Center for Development Studies and the National Democratic Institute for International Affairs, 12-14 March 1993).

The design of an electoral system is increasingly recognized as a key lever that can be used in the promotion of political accommodation and stability in ethnically divided societies. As Reynolds has observed, 'although appropriate electoral laws are insufficient to ensure stability and good governance in divided societies, poorly designed laws can entrench societal divisions and exacerbate pre-existing conflict' (Reynolds, 1995, pp. 86-100). In many African countries election results show the main political party as having overwhelming support in a core region. This is because, as Nwabueze has observed:

... for most African politicians the tribe is the base for political activity and tribal sentiment the focus of appeal which inevitably disables them from rising above tribal interests and pressures in the administration of government. The result is that the government comes to be regarded as one huge cake, already baked, and it is the duty of a political leader to secure for his tribe as large a share as possible. Every question, whether it be the award of scholarships or contracts, appointments in the public service, economic development or the siting of industrial projects are viewed from the standpoint of tribal advantage, 
and support or opposition to it dependent upon whether or not it advances the interests of one's tribe (Nwabueze, 1977, p. 17).

The system of winner-take-all, which is applied in most African countries, tends to reinforce this kind of approach to politics as it creates permanent losers and permanent winners. The winner-take-all system is based on the principle of territorial representation, emphasizing the relationship between the voter and the representative (des Villiers, 1993, p. 29). The size of a party's representation is thus determined not only by the number of votes received, but also by their geographical concentration. Should a party's votes be too widely scattered or too highly concentrated it could be under-represented in Parliament. In such a situation, groups that are numerically small can never win an election. They therefore remain permanently aggrieved. Such a system will be unable to implement democratic principles in deeply divided societies that are non-homogeneous (Bogdanor, 1987).

African countries need to re-examine the appropriateness of the proportional representation system to elections in their ethnically and racially divided societies in order to enhance democracy (Nadais, 1992, pp. 190-203). In a proportional representation system the political parties compete for support in multi-member constituencies and the division of seats is determined by the actual support that a party receives. The main objective of proportional representation, in contrast to the winner-take-all system, is to ensure that there is a proportional relationship between the votes received and the seats allocated to a particular party. The net effect of proportional representation is that all political parties, not only the majority or larger parties, are represented in accordance with their support base (de Villiers, 1993, p. 33). The experiences of South Africa and Namibia (du Pisani, 1993, p. 234) suggest that in ethnically divided societies the system of proportional representation in one form or another is more appropriate than that of the winner-take-all system. If minorities are to accept their legislature, they must be adequately represented in it. It is our argument that winner-take-all elections do not sufficiently address this issue (Lewis, 1965, p. 71).

The use of a winner-take-all system in the 1994 elections in South Africa would have had a number of negative consequences. The immediate result would have been a denial of parliamentary representation to critical minority parties such as the Freedom Party, Democratic Party and Pan Africanist Congress (PAC). Proportional representation allowed the South African Parliament to be fairly reflective of South African society as a whole (Final Report of the United Nations Observer Mission in South Africa, 1994). Nonetheless, a major criticism of proportional representation is that it allows extremist parties to gain representation in Parliament, thereby giving them legitimacy in society (Nadais, 1992, p. 193). There is also the perception that the system leads to coalitions and therefore weak governments. These objections are far outweighed by the benefits the system contributes to stability and representation of all population groups in a country. No government, not even one with a big majority, would be able to work effectively if its society were perpetually on the verge of permanent breakdown, aggravated by the threats of extra-constitutional action by under-represented minorities. Moreover, it would appear that proportional representation rather than the winner-take-all system is more in line with traditional African political organization. Traditional African society insisted that major decisions affecting the whole community should not be made by a bare majority of the society. Bentsi-Enchil has observed that 'our ancestors insisted that everything should be done on achieving the consensus of all key sectors of the community before a decision was made' (Bentsi-Enchil, 1969, p. 72).

After the choice of the electoral system, the second fundamental choice is whether to have a presidential or a parliamentary system. In a majority of African countries (such as Zambia, Zimbabwe, Tanzania, Ghana and Kenya), the president is chosen directly in a national election (Zambian Constitution, Articles 34 and 35, 1996). Good constitutional design for divided societies dictates against directly elected presidents. Shugart and Carey have identified three key traits of presidentialism that often have negative consequences: temporal rigidity, majoritarianism and dual democratic legitimacy (Shugart and Carey, 1999, pp. 28-43). In a divided society without a history of stable democracy, there is no assurance that the loser, or losers, of a presidential race will accept defeat in what amounts to a zero-sum game. Reid of the US State Department laid the blame for the collapse of peace plans in Angola in 1994 and the bloody conflict that ensued largely on the country's presidential system. He observed that Dos Santos and Savimbi were vying for the only prize worth having; it was inevitable that Savimbi 
would resume his violent struggle after losing the election. In Nigeria, the all-or-nothing structure of the 1993 presidential election made it easier than it would have been for the military to succeed in annulling the election before the final results had been officially announced. Unsuccessful candidates had no immediate stake in the political outcome, and many readily acquiesced in the election's annulment in the hope of being able to run again (Reid, 1993). In the Congo (Brazzaville), Sassou Nguesso in 1992 succumbed to popular pressure and permitted multi-party elections in which he stood as a candidate for President and lost the elections. After losing the election, he became obsessed with ousting his successor, Pascal Lissouba. He mounted a military campaign against his successor until he succeeded in regaining power in June of 1998 (Anglin, 1998).

Directly elected presidents typically interpret their mandate as distinct from that of the Members of Parliament, and as entitling them to supervise Parliament in its work. Another danger of a presidential system is that a directly elected President tends to be pressured into ethnic or regional exclusivity. Such Presidents have a great incentive to offer special privilege to their own ethnic or regional groups as a means of ensuring re-election through a simple majority or plurality of votes. The arrangement, where the President is elected by Parliament, is more conducive to formal and informal power-sharing arrangements. In such an arrangement, even without grand coalition requirements, minority parties can influence the choice of President and the composition of the Cabinet, particularly where there is no clear parliamentary majority (Gloppen, 1997, pp. 217-218). Given the factors discussed above, it would seem that a President elected by Members of Parliament would foster the feeling of greater participation in the election of all stakeholders in the country as represented in Parliament. South Africa (South African Constitution, Article 86, 1996) and Eritrea (Eritrean Constitution, 1996) are examples of African countries that presently follow this arrangement. The adoption of the parliamentary system for the election of a President would be an extension of the proportional representation system to the elections for the office of President.

\section{LEGITIMACY OF THE PROCESS OF DEVELOPING AND ELABORATING A CONSTITUTION}

The process of adopting a constitution is as important as its substance (Ndulo and Kent, 1996, p. 257). The process must be legitimate and, for it to be legitimate, it must be inclusive (Ramaphosa, 1995, p. 7). It should represent the interests of all the people in the country, and the people must be made to feel that they own the process and the end product (Ramaphosa, 1995, p. 7). A constitution should be the product of the integration of ideas from all the major stakeholders in a country, including all political parties - both within and without Parliament, organized civil society and individuals in the society (Ndulo and Kent, 1996, p. 256). Constitution-making structures must be open to the views and opinions of all stakeholders who must be given a meaningful opportunity to make their views known. If a constitution is to represent the aspirations and dreams of all the people, deliberate steps have to be undertaken to ensure that those who might be disempowered become part and parcel of the process (Mbeki, 1995, p. 10). The process must be transparent; it must be undertaken in full view of the country and the international community. The constitutional text must be in a simple language that is accessible to all. It should therefore be translated into all the major languages spoken in a given jurisdiction. A constitution that is perceived as having been imposed on a large segment of the population, or as having been adopted through the manipulation of the process by some of the stakeholders, is unlikely to gain sufficient popularity or legitimacy to endure the test of time. The process of constitution-making cannot, and should not, be determined solely by the government of the day, but by all stakeholders.

The post-independence constitutions in Africa were the result of agreements reached at independence conferences which followed nationalist campaigns for independence (Zambian Constitution, 1995). The texts of the constitutions bequeathed to the new states followed colonial models developed by the various colonial powers for newly independent states. Mozambique, Namibia, Angola and South Africa followed rather different paths because protracted liberation struggles preceded independence in those countries. One of the unfortunate legacies of the colonial model has been the extremely detailed approach in African constitutions. For example, a typical 
African constitution contains hundreds of detailed provisions which might, in effect, undermine its dynamic development and its ability to meet the needs of a rapidly changing society (Zambian Constitution, 1993).

Since independence, the practice in many African countries has been to adopt new constitutions through the use of commissions (Report of the Constitutional Review Commission, 1995). The commission typically tours the country, soliciting views relating to possible constitutional arrangements from the public, and ends its work by recommending a draft constitution for adoption by the national legislature. This approach fails to produce durable and lasting constitutions for many of the countries that have used it. Zambia is a case in point where the opposition parties continue to dispute the constitution adopted in May 1996 on the grounds that it does not reflect the views of the Zambian people and that the process was manipulated by the ruling party (Report of Citizens Convention on the Draft Constitution, 1996). This experience and others suggest that the use of commissions to recommend a constitution is susceptible to manipulation by the government in power and often results in the imposition of its preferred constitutional model. Matters are made worse by the perception held by most people that such commissions are populated by people sympathetic to the ruling party. Moreover, on practical grounds too, the use of a commission with a broad and unregimented agenda, to collect constitutional proposals, is inappropriate for the elaboration of a complex document such as a constitution.

A major drawback of the commission method as practised in Africa is that people come to the commission hearings and, without any guidance whatsoever, voice their opinions about what they individually consider to be constitutional issues (Report of the Constitutional Review Commission, 1995, p. 3). Typically, the issues they address are not appropriate for inclusion in a national constitution. A large number of petitioners take advantage of the process to air grievances relating to unemployment, land allocation, lack of schools, lack of health care, inadequate transport facilities and development rather than those relating to the constitution. Questions of relevance and weight to be attached to the individual submissions are glossed over for political or expediency reasons, or for decorum. It is this scenario that provides a perfect opportunity for the government in power to manipulate the constitution-making process. Besides, with thousands of submissions, an average lawyer could easily write any number of versions of a constitution and find justification in the submissions made to the commission for each one of them. South Africa and Namibia stand out as unique in the process they adopted in elaborating their national constitutions (Cottrell, 1991). In both countries, constitutions were adopted by democratically elected constituent assemblies specially elected to elaborate a national constitution. This process ensured that in each of these countries, before the country's constitution was adopted, there were extensive consultations with the people and all the principal stakeholders (Gloppen, 1997, pp. 165-264). It is imperative that a broad spectrum of people discuss and voice their opinions as to what the proper constitutional arrangements for the country should be. In Africa, the difficult question is how to do this effectively so as to prevent the manipulation of the system by the party in power. The South African experience teaches us that, to meet the need for the widest possible segment of the population, and to make the widest possible consultations meaningful, the method of consultation must be properly structured so that there are meaningful and open discussions. An appropriate strategy would be to select a group of experts representative of all the political parties operating in the country and of the other stakeholders to draw up a draft constitution. The drafting should be informed by theme committees set up as part of the structure to facilitate public participation in the exercise (South Africa, Debates of the Constitutional Assembly, 1995, p. 3). For example, the South African constitutional exercise was organized along the following six themes: character of democratic state, the structure of government, the relationship between levels of government, fundamental rights, judiciary and legal systems, and specialized structures of government (Ebrahim, 1995).

The main task of the committees would typically be to gather/collate and to refine the views of the political parties and the public on specific issues, and submit them to the constitution-making body. The draft constitution, as established by the constitution-making body, should be based on a list of constitutional principles established and agreed to by all the stakeholders before the drafting exercise commences. It should also be accompanied by commentaries on each of the provisions contained in the draft constitution analysing the various aspects of the constitution, highlighting options and identifying problems and difficulties that might be incurred in the application of the various suggested provisions. Such a document should then be subjected to public scrutiny and analysis 
in a forum such as a constitutional assembly that has specifically been elected to elaborate a constitution. This approach would structure the ensuing debate along specific constitutional themes. The existence of a draft would serve to limit the perimeters of discussion to constitutional issues and to avoid the practice of petitioners addressing the commission on every aspect of human endeavour.

\section{METHOD OF ADOPTION AND ENACTMENT OF THE CONSTITUTION INTO LAW}

After a constitution is elaborated, the next question that arises is how to involve the people in the adoption of the draft constitution so as to give it maximum legitimacy. The supreme law of the land should not be adopted using the same procedures as those that are available for ordinary legislation (Report of the Constitutional Review Commission, Government of the Republic of Zambia, 1995, p. 64). A constitution should have sanctity, and should not be subjected to willful amendments (Zambian Constitution, Article 72, 1991). There are two methods that have been used in the adoption of constitutions in Africa in the post-colonial period, which are:

- adoption through a two-thirds majority in Parliament; and

- adoption through a constituent assembly or national referendum.

It could be argued that the adoption of the constitution through a constituent assembly or referendum is unnecessary, as the enactment of a constitution is the legislative preserve of the legislature (Mwanakatwe Constitutional Review Commission Supplement, Republic of Zambia, 1995). Whether the legislature has power to enact a constitution or not is not the issue. The real question is: how do you ensure that the sovereign will of the people on which the edifice of democracy rests occupies centre stage in the process of producing a legitimate, credible and enduring constitution? If anything, the process of consulting the people strengthens Parliament as it implies an unequivocal acceptance of the fact that Parliament's powers are delegated to it by the people. The relationship between Parliament and the people can only endure where it is realized and accepted that the people are supreme. Therefore, in matters of great national importance, such as the adoption of a national constitution, Parliament must consult and defer to the wishes of the people who, after all, are the source of popular sovereignty (Nwabueze, 1973, p. 1305). A successful constitution is one which obtains legitimization by popular will (Nwabueze, 1973, p. 25). Popular democracy demands the institutionalization of a culture of consultation and reciprocal control with regard to law-making and the use of power and privileges. The adoption of a constitution through a referendum is one of the most transparent ways of furthering the culture of consultation in a democracy.

Simply requiring a two-thirds vote in Parliament to approve a constitution is not an effective safeguard against the adoption of an unpopular or unfair constitution or amendments to it. The two-thirds majority requirement is often within the reach of the largest party in Parliament, especially in a winner-take-all electoral system (Ndulo and Kent, 1996, p. 264). The requirement is therefore, in practice, not much more than the simple majority required for ordinary law-making. In order to safeguard democracy, much more should be required to effect a constitutional amendment than the will of the majority party in Parliament. Popular consultation in the form of a referendum should in fact be entrenched in African constitutional practice as a mechanism for obtaining the mandate of the people on constitutional matters and as a deterrent to amendments. In addition, the involvement of the people in the adoption of a national constitution is an educational experience for them and enables them to focus on the contents of the constitution in a manner they would not do otherwise. Once adopted, the constitution should have sanctity, and should not be subject to willful amendments. To emphasize this point, the Namibia constitution has adopted a novel approach. It provides that the bill of rights provisions in the constitution may not be diminished or detracted from through amendments and any such purported repeal or amendment shall be invalid (Constitution of Namibia, Article 131, 1989). Recent events in Namibia to amend the constitution and remove the two-term limitation on the presidency in order to facilitate the incumbent President serving a third term are regrettable and can only serve to undermine the sanctity of the Namibian constitution and the development of democracy in that country (Mail Guardian, Johannesburg, 31 October 1998). 


\section{CONCLUSION}

Some have expressed scepticism at the viability of democracy in African societies with deep ethnic divisions, widespread illiteracy, lack of a sizeable middle class, lack of vibrant civil society, lack of a political culture of tolerance, debate and compromise, in the face of the huge economic and environmental hardships that confront Africa (Wing, 1995, p. 762). Indeed Africa's economic conditions are exacerbated by the debt crisis (debt service obligations claim two-thirds of some countries' budgets). When this is added to demographic and cultural problems, some ask whether democracy can take root in Africa. In response, it should be pointed out that there is already substantial evidence that democratic institutions can and are prospering on the African continent. African states, no longer constrained by ideological divisions, are facing the African crisis boldly. They have evidenced a greater readiness to acknowledge their collective responsibility for promoting conditions of peace, good governance and respect for human rights throughout the continent. Moreover, there is welcome evidence of increased political will to intervene actively to contain, to resolve, or even to suppress domestic conflicts. Interventions in Lesotho and Sierra Leone are examples of the changes that have occurred in this sphere. There is continent-wide acceptance of multi-partyism and of the direct link between good governance and development. There are currently several African countries such as Botswana, Mozambique and South Africa that qualify as vibrant democracies. They are not enough but are nevertheless sufficient to prove that democracy has a home in Africa. Their experience could form the building blocks for more democratic systems.

Finally, we would like to observe that, throughout the world, evidence of performance at both political and economic levels repeatedly calls attention to the importance of effective political leadership. Popular democracy requires responsible leaders and enlightened followers. The values and skills of political leaders have figured prominently in the nurturance or destruction of democracy in many parts of the world. Nothing written in the constitution has any meaning unless it is written in the hearts of the people. As Judge Learned Hand observed, 'I often wonder whether we do not rest our hopes too much upon constitutions, upon laws and upon courts. These are false hopes; believe me, these are false hopes. Liberty lies in the hearts of men and women; when it dies there, no constitution, no law, no court can save it; no constitution, no law, no court can even do much to help it' (Hand, 1960, pp. 189-190).

African nations should take additional measures to cultivate a democratic culture in their countries. Clear ways and means of nation-building and promoting the culture and habit of democratic self-governance as well as the ethos of human rights and obligations, cooperative governance and multi-cultural tolerance and harmony should be developed. Civic education is needed to enlighten the public concerning their rights in making institutions accountable, so that the people are able to resist the 'know-it-all' attitude of some government officials. Further, a constitution once adopted should be popularized among the people and made accessible to ordinary men and women by having it translated into the main languages spoken in the country and holding workshops to discuss the content. The future of democracy in Africa depends on the development of political systems that give people a sense of ownership of the political process. The transition from authoritarianism to greater participation in political decision-making requires determined long-term efforts. The enormous size of the challenge should not be underestimated. But concerted efforts to overcome the obstacles could ensure that Africa is firmly established on the road to democracy and development.

\section{REFERENCES}

Agunda AT. 1983. The Judiciary in the Government of Nigeria.

Ampem II NW. 1995. The role of chiefs and chieftaincy in the development of a democratic constitutional Ghana. International Round Table on Democratic Constitutional Development, Pretoria, South Africa.

Andrews P. 1995. Affirmative action in South Africa: some theoretical and practical issues. In The Constitution of South Africa from a Gender Perspective, Liebenberg S (ed.).

Andrews P. 1998. Uhuru at last! now what about the women? Women and rights in the new South Africa. In The New South African Constitution and the Enforcement of Rights, Andrews P, Ellmann S (eds).

Anglin D. 1994. Conflict in Sub-Saharan Africa, 1993-1994. Carleton University: Ottawa, Canada.

Anglin D. 1998. Conflict Resolution in Sub-Saharan Africa, 1997-1998. Carleton University: Ottawa, Canada. 
Bentsi-Enchill K, 1969. Civitas Dei Africa: realizing the African political dream. Zambian Law Journal 2(1): 65.

Bogdanor V. 1987. The Backwell Encyclopuedia of Political Institutions.

Chaskalson A. 1995. President of the South African constitutional court. Opening Speech to the International Round Table on Democratic Constitutional Development, Pretoria, South Africa.

Chazon N. 1988. Politics and Society in Contemporary Africa, Lynne Reinner, Boulder, CO.

Chikulo BC. 1984. Decentralization in centralism: an analysis of the Zambian experience 1964-1981. In Issues in Zambian Development, Osei-Hwedie K. Ndulo M (eds); 34.

Cottrell J, 1991. Constitution of Namibia: an overview. Journal of African Law 35(1-2).

Davidson B. 1992. Black Man's Burden: Africa and the Curse of the Nation State, Times Books: New York.

des Villiers B. 1993. An electoral system for the new South Africa. In Consitution-Making in the New South Africa, Johnson A, Shezi S, Bradshaw G (eds); 29.

du Pisani A. 1993. Namibia: the making of a new state in the region. In Constitution-Making in the New South Africa, Johnson A, Shezi S, Bradshaw G. (eds).

Ebrahim H. 1995. The Process of Drafting South Africa's new constitution. International Round Table on Democratic Constitutional Development, Pretoria, South Africa.

Fiss OM. 1996. Liberalism Divided: Freedom of Speech and the Many Uses of State Power.

Fourth Conference on Women. 1985. Platform for Action and the Beijing Declaration, Beijing, 4-15 September, 1985.

Gertzel C, Baylis C, Szeftel M. 1994. The End of the Kauanda Era.

Gloppen S. 1997. South Africa: The Battle Over the Constitution, Darmouth Publishing, New Hampshire.

Gluckman M. 1967. The Judicial Process Among the Barotse of Northern Rhodesia.

Hand L. 1963. The Spirit of Liberty, Knopf: New York.

Hel D. 1996. Models of Democracy, Stanford University Press, Stanford, CA.

Howard R. 1996. Human Rights in Commonwealth Africa, Rowman \& Littlefield: New York.

Lancaster C. 1991. Democracy in Africa, Foreign Policy 85.

Lugard FD. 1905. The Dual Mandate in British Tropical Africa.

Mbeki T. 1995. Republic of South Africa: Debates of the Constitutional Assembly, no. 1, p. 11, Cape Town, South Africa.

Mubako S. 1973. Zambia's single-party constitution: a search for unity and development. Zambian Law Journal 5: 67.

Museveni Y. 1977. Sowing the Mustard Seed: The Struggle for Freedom and Democracy in Uganda.

Nadais A. 1992. Choice of Electoral Systems, in New Democratic Frontier, National Democratic Institute: Washington, DC; $190-203$.

Ndulo M. 1981. Liability of a paramour in damages for adultery in customary law, African Social Research 28: 179.

Ndulo M. 1997. The 1996 Zambian constitution and the search for a durable democratic constitutional order in Africa, African Yearbook of International Law 5: 174.

Ndulo M, Kent R. 1996. Consitutionalism in Zambia: past, present and future. Journal of African Law 40(2): 257.

Nhlapo N. 1991. The African family and women's rights: friends or foes? Act Juridica 135.

Nhlapo N. 1995. Accommodating traditional forms of governance in a constitutional democracy: a motivation. International Round Table on

Democratic Constitutional Development, Pretoria, South Africa.

Nwabueze BO. 1973. Constitutionalism in the Emergent States. St. Martin's Press, New York.

Nwabueze BO, 1977. Judicialism in Commonwealth Africa. St. Martin's Press, New York.

Obasanjo O. 1988. Africa in today's world. Paper presented at the Africa Leadership Forum, Ota, Nigeria.

Ojwang JB. 1990. Constitutional Development in Kenya.

Paul J. 1988. Developing constitutional orders in sub-Saharan Africa: an unofficial report. Third World Legal Studies 5.

Platform for Action and the Beijing Declaration. 1995. Fourth Conference on Women, Beijing, China; 17.

Ramaphosa C. 1995. Republic of South Africa: Debates of the Constitutional Assembly, Cape Town, South Africa, 24 January-20 February, Reid A. 1993. Conflict resolution in Africa: lessons from Angola. INR Foreign Affairs Brief. US Department of State: Washington, DC.

Reynolds A. 1995. Constitutional engineering in Southern Africa. Journal of African Democracy 6(1): 86-100.

Seidman R. 1987. Perspectives on constitution-making independence constitutions of Namibia and South Africa. Lesotho Law Journal 3: $45,56$. Singhvi L. 1995. Democracy and the constitution. International Round Table on Democratic Constitution Development, Pretoria, South Africa. Shugart M, Carey J. 1999. Presidents and Assemblies: Constitutional Design and Electoral Dynamics.

Simeon R. 1995. The structures of intergovernmental relations. International Round Table on Democratic Constitutional Development Conference, Pretoria, South Africa.

Simons HJ. 1968. African Women: Their Legal Status in South Africa.

Third World Legal Studies. 1988. Building Constitutional Orders in Sub-Saharan Africa.

Van der Vyer JD. 1991. Constitutional options for post-apartheid South Africa. Emery L. J. 40: 745, 822.

Wing. A. (1995). Towards democracy in a new South Africa. Michigan Journal of International Law 690.

Yansane A. 1996. Prospects for Recovery and Sustainable Development in Africa. Greenwood Publishing Group.

Zimba L. 1984. The origins and spread of one-party states in Commonwealth Africa, their impact on personal liberties: a case study of the

Zambian model. In Law in Zambia, Ndulo M (ed.). 